\title{
Ferrocyanide Safety Program: Analysis of Postulated Energetic Reactions and Resultant Aerosol Generation in Hanford Site Waste Tanks
}

\author{
A. K. Postma \\ G \& P Consulting, Inc. \\ D. R. Dickinson \\ Westinghouse Hanford Company \\ Date Published \\ September 1995
}

Prepared for the U.S. Department of Energy

Assistant Secretary for Environmental Management

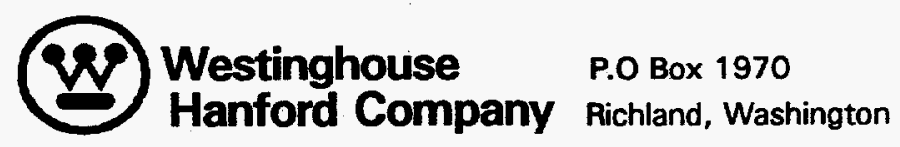

Management and Operations Contractor for the

U.S. Department of Energy under Contract DE-AC06-87RL10930

Approved for public release; distribution is unlimited 


\section{RELEASE AUTHORIZATION}

Document Number: WHC-EP-0876

$\begin{array}{ll} & \text { Ferrocyanide Safety Program: Analysis of Postulated } \\ \text { Document Title: } & \text { Energetic Reactions and Resultant Aerosol Generation }\end{array}$ in Hanford Site Waste Tanks

Release Date: $\quad 9 / 26 / 95$

This document was reviewed following the procedures described in WHC-CM-3-4 and is:

APPROVED FOR PUBLIC RELEASE

WHC Information Release Administration Specialist:

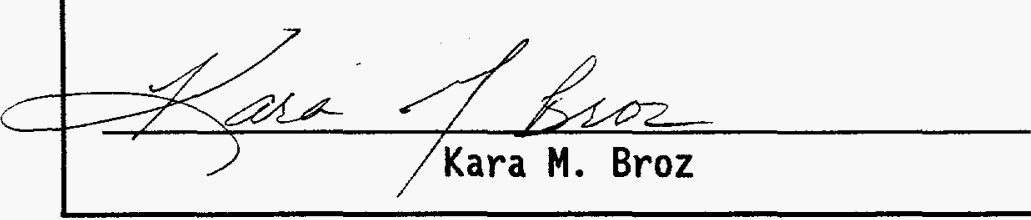

September 26, 1995 


\section{DISCLAIMER}

This report was prepared as an account of work sponsored by an agency of the United States Government. Neither the United States Government nor any agency thereof, nor any of their employees, make any warranty, express or implied, or assumes any legal liability or responsibility for the accuracy, completeness, or usefulness of any information, apparatus, product, or process disclosed, or represents that its use would not infringe privately owned rights. Reference herein to any specific commercial product, process, or service by trade name, trademark, manufacturer, or otherwise does not necessarily constitute or imply its endorsement, recommendation, or favoring by the United States Government or any agency thereof. The views and opinions of authors expressed herein do not necessarily state or reflect those of the United States Government or any agency thereof. 


\section{DISCLAIMER}

Portions of this document may be illegible in electronic image products. Images are produced from the best available original document. 


\section{CONTENTS}

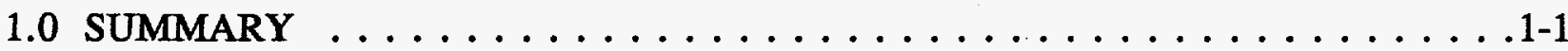

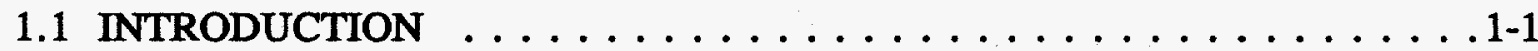

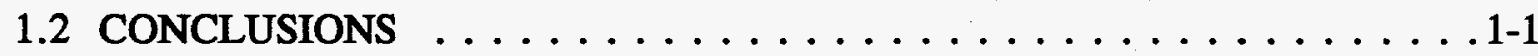

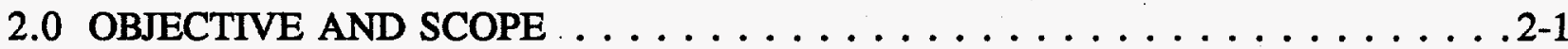

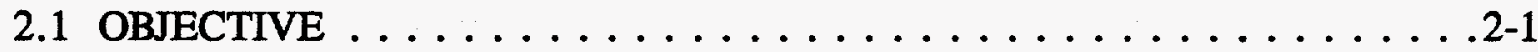

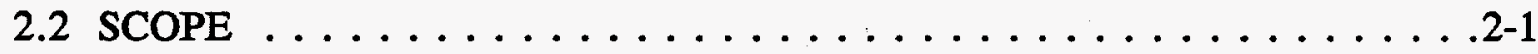

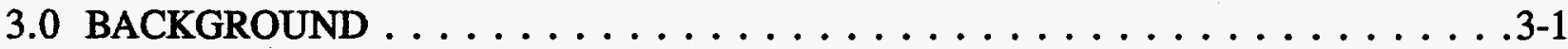

3.1 WASTE CREATION $\ldots \ldots \ldots \ldots \ldots \ldots \ldots \ldots \ldots . . \ldots \ldots$

3.2 POTENTIAL HAZARD OF UNCONTROLLED EXOTHERMIC

REACTIONS IN FERROCYANIDE WASTE . . . . . . . . . . 3-1

3.3 EXPLOSION IN FERROCYANIDE TANK POSTULATED IN 1987 ENVIRONMENTAL IMPACT STATEMENT $\ldots \ldots \ldots \ldots \ldots \ldots . \ldots .2$

3.4 GAO REVIEW OF EIS DOSE ASSESSMENTS . . . . . . . . . . 3-3

3.5 DECLARATION OF FERROCYANIDE UNREVIEWED SAFETY QUESTION (USQ) . . . . . . . . . . . . . . . . 3-4

4.0 REVIEW OF FERROCYANIDE SAFETY STUDIES . . . . . . . . . . . 4-1

4.1 IDENTIFICATION OF FERROCYANIDE TANKS . . . . . . . . . 4-1

4.2 DOE TASK TEAM REVIEW OF GAO AND EIS ASSESSMENTS . . . . 4 4-1

4.3 REVIEW OF SINGLE-SHELL TANK WASTE STABILITY $\ldots \ldots \ldots \ldots 4-2$

4.4 WESTINGHOUSE HANFORD COMPANY

AEROSOL EXPERTS PANEL REVIEWS $\ldots \ldots \ldots \ldots \ldots \ldots \ldots$. . . . . . .

4.4.1 Meeting of December $18,1990 \ldots \ldots \ldots \ldots \ldots \ldots \ldots \ldots$. . . . . . . .

4.4.2 Meeting of March 2, $1992 \ldots \ldots \ldots \ldots \ldots \ldots$. . . . . . . . 4-3

4.5 REPORT OF HIGH-LEVEL WASTE TANKS ADVISORY PANEL . . . . 4-4

4.6 WESTINGHOUSE HANFORD COMPANY HAZARDS ANALYSIS

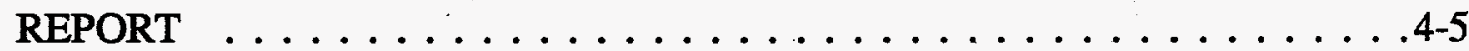

4.6.1 Moisture Retention of Ferrocyanide Waste . . . . . . . . . . 4-5

4.6.2 Compositional Limits for Propagating Reactions . . . . . . . . . . 4-6

4.6.3 Cesium Distribution in Waste Tanks . . . . . . . . . 4-6

4.6.4 Flowsheets for Ferrocyanide Sludge . . . . . . . . . . . . . 4-6

4.7 CURRENT UNDERSTANDING SNAPSHOT - NOVEMBER $1991 \ldots \ldots$. . 4-6

4.8 RESEARCH STUDIES $\ldots \ldots \ldots \ldots \ldots \ldots \ldots \ldots \ldots$. . . . . . . . . . . .

4.8.1 Westinghouse Hanford Company Studies . . . . . . . . . 4-7

4.8.2 Reaction Studies at Fauske and Associates, Inc. . . . . . . . . 4-8

4.8.3 Pacific Northwest Laboratory Studies . . . . . . . . . . . . 4-11

4.8.4 Los Alamos National Laboratory Studies . . . . . . . . . . . 4-11

4.9 FAILURE LIMITS OF WASTE TANKS $\ldots \ldots \ldots \ldots \ldots \ldots \ldots$. . . . . . .

4.10 DEFINITION OF SAFETY CRITERIA . . . . . . . . . . . . . 4-13

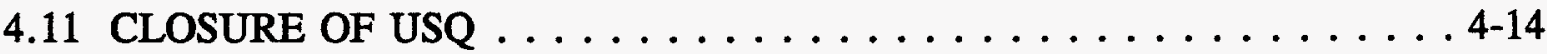




\section{CONTENTS (Continued)}

5.0 CURRENT UNDERSTANDING OF THE SAFETY

OF FERROCYANIDE WASTE $\ldots \ldots \ldots \ldots \ldots \ldots \ldots \ldots$. . . . . . .

5.1 SUMMARY OF IMPORTANT RESULTS OF FERROCYANIDE

STUDIES . . . . . . . . . . . . . . . . . 5-1

5.2 PRESENT NEED FOR CONSEQUENCE ANALYSIS AND

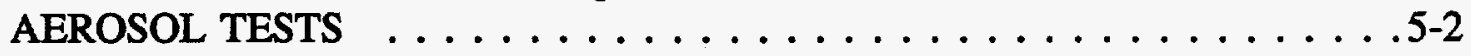

6.0 REFERENCES . . . . . . . . . . . . . . . . . 6-1

\section{LIST OF TABLES}

4-1 Exotherms of.Tank Samples $\ldots \ldots \ldots \ldots \ldots \ldots \ldots \ldots \ldots \ldots \ldots$ 4-8

4-2 Measurements of Propagation Velocity $\ldots \ldots \ldots \ldots \ldots \ldots \ldots . . \ldots \ldots$ 


\section{LIST OF TERMS}

DOE

EIS

FAI

GAO

PNL

PRC

TAP

TRAC

USQ

WHC
U.S. Department of Energy environmental impact statement

Fauske and Associates, Inc. Government Accounting Office

Pacific Northwest Laboratory

Plant Review Committee

Tank Advisory Panel

track radioactive components

unreviewed safety question

Westinghouse Hanford Company 
WHC-EP-0876

This page intentionally left blank. 


\section{FERROCYANIDE SAFETY PROGRAM: ANALYSIS OF POSTULATED ENERGETIC REACTIONS AND RESULTANT AEROSOL GENERATION IN HANFORD SITE WASTE TANKS}

\subsection{SUMMARY}

\subsection{INTRODUCTION}

This report reviews work done to estimate the possible consequences of postulated energetic reactions in ferrocyanide waste stored in underground tanks at the Hanford Site. The issue of explosive reactions was raised in the 1987 Environmental Impact Statement (EIS) (DOE 1987), where a detonation-like explosion was postulated for the purpose of defining an upper bound on dose consequences for various disposal options. A review of the explosion scenario by the General Accounting Office (GAO) (Peach 1990) indicated that the aerosol generation and consequent radioactive doses projected for the explosion postulated in the EIS were understated by one to two orders of magnitude. The U.S. Department of Energy (DOE) has sponsored an extensive study of the hazard posed by uncontrolled exothermic reactions in ferrocyanide waste, and results obtained during the past three years have allowed this hazard to be more realistically assessed.

The objective of this report is to summarize the improved knowledge base that now indicates that explosive or vigorous chemical reactions are not credible in the ferrocyanide waste stored in underground tanks. This improved understanding supports the decision not to proceed with further analyses or predictions of the consequences of such an event or with aerosol tests in support of such predictions.

\subsection{CONCLUSIONS}

The hazard of concern is an exothermic reaction between ferrocyanides and nitrates and nitrites contained in sludge waste. Laboratory tests have demonstrated that these chemicals can react violently if they are pure, are present in stoichiometric proportion, are dry, and are heated to temperatures above $250^{\circ} \mathrm{C}$. However, current information indicates that ferrocyanide sludge is composed mainly of inert chemicals and has a high water content; thus, the waste cannot support a self-sustaining reaction and cannot undergo the explosion scenario that had been postulated in both the 1987 EIS (DOE 1987) and in the GAO report (Peach 1990).

Current storage conditions (passively ventilated underground tanks) foster the retention of moisture and the passive dissipation of nuclear decay heat. Decay heat loads are known to decrease with time, and tank samples and laboratory studies indicate that ferrocyanides have 
degraded over the four decades of storage history. Therefore, hazards posed by uncontrolled exothermic reactions are expected to further diminish with continued storage time.

The explosive accident scenarios analyzed in earlier reports (DOE 1987, Peach 1990) were based on a "worst case" series of assumptions that was characterized at the time (Burger 1984) as being of very low probability. Because sufficient information was not then available to rule out the "worst case," the series of assumptions was used to identify upper bound consequences. Recent information (Postma et al. 1994) indicates that the ferrocyanide sludges present in the Hanford Site waste tanks cannot burn or explode, and therefore that the doses predicted for detonation scenarios are not meaningful because they were not based on credible events.

Recent aging studies (Lilga et al. 1993, 1994) have shown that the combined effects of temperature, radiation, and $\mathrm{pH}$ during 38 years or more of storage would have destroyed most of the ferrocyanide originally added to the tanks. This prediction has been confirmed by those tank samples that have been analyzed to date. The resultant sludge is too dilute to support a sustained reaction, even if dried out and ignited.

Several DOE-sponsored studies (Kress et al. 1990, Postma et al. 1992a) have been initiated to better quantify the consequences of an uncontrolled ferrocyanide-nitrate/nitrite reaction. An unresolved problem was the generation of aerosols under realistic tank conditions. Aerosol tests to quantify aerosol parameters were therefore planned (Postma et al. 1992a). As information on moisture levels and energetics became available, it became apparent that actual sludge would not burn or explode (Fauske 1992). Considering cost priorities, and the low probability of waste dispersive accidents, the proposed aerosol test program was never carried out.

Measurements of the velocity of propagation of a chemical reaction through simulants of the most energetic of the originally added ferrocyanide sludges show velocities of only 1 to 5 millimeters per second (mm/s) (Fauske 1992, 1993a, and 1993b). These velocities are orders of magnitude lower than what are generally considered to be explosions, and even further below the sonic velocities characteristic of detonations. The rate of input of mechanical energy from these reactions is too small for the efficient production of respirable aerosols by mechanical breakup. The dominant aerosol production mechanism is then vaporization and subsequent recondensation of the volatile species, principally cesium compounds. The rate of generation of aerosols by this mechanism can be calculated from thermodynamic considerations, given the temperature and gas generation rate. Therefore, the tests to measure aerosol generation from a ferrocyanide explosion, which had been proposed earlier, are not needed.

Although uncontrolled ferrocyanide-nitrate/nitrite reactions are not credible during continued in situ storage, residual exothermic activity might be initiated by disposal options that caused waste to be heated by an external energy source. The impact of the ensuing self-heating on the safety of a heating process will be evaluated on a case-by-case basis as part of the safety analysis of the proposed retrieval and processing methods. 


\subsection{OBJECTIVE AND SCOPE}

\subsection{OBJECTIVE}

The chief objective of this report is to provide a technical justification for why tests to measure aerosol generation from ferrocyanide reactions were dropped as unnecessary from the planned ferrocyanide program. The report also considers the closely related question of why it was decided to be unnecessary to proceed to completion with studies of the consequences of postulated ferrocyanide reactions in the waste tank.

A second objective of this report is to show how our perception of a possible ferrocyanide accident has changed as information has become available from research studies.

The approach to meet this objective is by review of previously published works that have led to a conclusion that a destructive ferrocyanide reaction in the Hanford Site waste tanks is not possible and that aerosol tests are not needed to provide a tank safety envelope.

\subsection{SCOPE}

This report reviews key documents that deal with hypothetical energetic reactions in ferrocyanide wastes stored in underground tanks at the Hanford Site. The focus is on waste conditions applicable to continued in-situ storage. Changes in waste state that could affect waste stability are briefly noted in order to illustrate the kinds of changes that could diminish waste stability. 


\section{WHC-EP-0876}

This page intentionally left blank. 


\subsection{BACKGROUND}

\subsection{WASTE CREATION}

Ferrocyanide waste was created at the Hanford Site in the 1950 s by means of a precipitation process that removed radiocesium from tank waste liquids. The aqueous wastes were treated with ferrocyanide and nickel salts to form a precipitate of sodium nickel ferrocyanide (Borsheim and Simpson 1991, Jeppson and Wong 1993). The precipitate, composed of fine particles enriched in radionuclides, settled into a sludge. The sludge was retained within the tank farm; this sludge, as modified by waste transfers and $38+$ years of aging, constitutes the ferrocyanide waste in the tanks today.

Approximately 140 metric tons of ferrocyanides were added to waste now contained in 18 single-shell tanks. Three different flowsheets (and variations of them) were used in ferrocyanide waste scavenging campaigns. Approximately $66 \%$ of the total ferrocyanide used at the Hanford Site was used in the "U-Plant" flowsheet. Simulant sludge produced by this flowsheet contained approximately 8.3 weight percent (wt\%) sodium nickel ferrocyanide. (This and the following concentrations are on a dry basis.) The "T-Plant" flowsheet consumed approximately $8 \%$ of the ferrocyanide used at the Hanford Site, and simulant sludge produced by this flowsheet contained $8.8 \mathrm{wt}$.\% sodium nickel ferrocyanide. The In-Farm flowsheet consumed approximately $26 \%$ of the ferrocyanide used at Hanford and produced sludge containing up to $25.8 \mathrm{wt} \%$ sodium nickel ferrocyanide. A more detailed review of ferrocyanide waste production is presented by Postma et al. (1994), and by Jeppson and Wong (1993).

\subsection{POTENTIAL HAZARD OF UNCONTROLLED EXOTHERMIC REACTIONS IN FERROCYANIDE WASTE}

Ferrocyanide waste contains mixtures that include ferrocyanides and nitrates. Some of the nitrates became converted to nitrites under the high radiation present in these tanks. These chemicals, when dry, pure, and heated to elevated temperatures (approximately 250 to $300{ }^{\circ} \mathrm{C}$ ), can react explosively. The potential hazard posed by ferrocyanide waste is an uncontrolled exothermic reaction that could cause radioactive aerosols to be ejected from storage tanks.

The potential for exothermic reactions between ferrocyanides and nitrates/nitrites was recognized by Hanford Site scientists since the 1950s (Burger 1984), but an analysis of this hazard was first made by Burger (1984). Six key assumptions made by Burger for the "worst case" scenario were as follows:

1. (6-8) $\times 10^{4}$ moles of $\mathrm{Fe}(\mathrm{CN})_{6}^{-4}$ had been put into one tank.

2. Ferrocyanide sludge settled into a pocket of $100 \mathrm{~m}^{2}$ area and 10 to $20 \mathrm{~cm}$ deep. 
3. Nitrate salts deposited with the ferrocyanide precipitate.

4. The ferrocyanide and nitrate salts compacted and dried before appreciable decomposition could take place.

5. Decay heat from radiocesium and other radionuclides increased the waste temperature as the waste dried out.

6. The ignition temperature was reached and reaction energy (calculated to be $1.5 \times 10^{8}$ kilojoules $[\mathrm{kJ}]$ ) was released in one second. (This energy is equivalent to 36 tons of TNT).

While Burger (1984) did not analyze the consequences of this "worst case" scenario, it is evident that an explosion of 36 tons of TNT could eject a significant quantity of waste from the buried tank and generate a significant quantity of respirable radioactive aerosol. Burger noted that the "worst case" scenario was highly improbable, but that sufficient information was not then available for a realistic analysis of the hazard.

On the basis of information gathered since Burger's report was completed, it is now known that a number of the six assumptions listed above are unrealistic. As will be discussed later in this report, the explosive reaction postulated in the "worst case" scenario is impossible because:

1. The sludge has not settled into thin pure layers 10 to $20 \mathrm{~cm}$ deep as had been postulated.

2. The reaction of ferrocyanide is relatively slow (not an explosion), even for the most concentrated ferrocyanide sludge added to any tank and even when dry.

3. Appreciable degradation has occurred during storage and present ferrocyanide concentrations are much lower than when the waste was originally added to the tank.

4. Decay heat loads are too low to heat waste to an ignition temperature.

5. Waste retains high moisture contents even after drainable liquid has been pumped out or lost by leakage; the ferrocyanide sludge has not and cannot become dried out.

\subsection{EXPLOSION IN FERROCYANIDE TANK POSTULATED IN 1987 ENVIRONMENTAL IMPACT STATEMENT}

An explosion in a ferrocyanide waste tank was postulated as a means of quantifying an upper bound release of radioactive material in operations for final disposal of Hanford Site waste 
(DOE 1987). The postulated explosion was predicted to cause radiation doses to the public of a magnitude comparable to background radiation. The maximum 70-yr committed dose to an on-site worker was computed to be $20 \mathrm{rem}$, with bone being the critical organ.

The technical basis for the postulated ferrocyanide tank explosion is summarized in a Pacific Northwest Laboratory (PNL) report (Mishima et al. 1986). The explosion was postulated to result from an operation in which solid waste was retrieved from underground tanks. Following the lead of the Burger (1984) "worst case" scenario, the explosion was assigned an energy equivalent of 36 tons of TNT. Aerosol generation from the assumed detonation of ferrocyanides was analyzed using a correlation presented by Steindler and Seefeldt (1980) which relates the dispersion (particle size and initial aerosol mass) of an inert material surrounding an explosive to the ratio of inert mass to mass of TNT explosive. For the postulated explosion, the initial aerosol mass released to the atmosphere was calculated to be $5 \times 10^{8} \mathrm{~g}$, of which $1.3 \times 10^{4} \mathrm{~g}$ was estimated to be in the respirable particle size range, e.g., less than $10 \mu \mathrm{m}$ aerodynamic equivalent diameter.

The analytical method used to estimate the aerosol source term listed above does not account for material within the explosive itself. Materials contained within the explosive itself would be likely to be aerosolized to a greater extent than would inert materials external to the explosive. This issue is relevant to a postulated ferrocyanide explosion because the material assumed to explode (sodium and cesium nickel ferrocyanide mixed with sodium nitrate and nitrite) is enriched in radionuclides (particularly cesium and strontium) as compared to surrounding saltcake. This issue was raised in the GAO audit (Peach 1990) of the 1987 EIS dose calculations, as is discussed in the following section.

The ferrocyanide explosion described above was assumed by Mishima et al. (1986) to be applicable only to waste disposal efforts that involved retrieval or in-tank processing. For a continued in situ storage option, the explosion was not considered to be credible because wastes "... are left undisturbed" (Mishima et al. 1986).

\subsection{GAO REVIEW OF EIS DOSE ASSESSMENTS}

A GAO review (Peach 1990) of dose calculations presented in the 1987 EIS concluded that the bounding consequences of an explosion in a ferrocyanide tank had been understated. The GAO review focused mainly on the consequences of a postulated explosion having a TNT energy equivalent of explosions described by Burger (1984) and by the EIS (DOE 1987). The GAO report indicated "....although the probability of an explosion may in fact be low, not enough is known about the waste in the single-shell tanks to definitely rule out the possibility of a spontaneous explosion."

As discussed in the GAO review, cesium-137 and strontium-90, would be contained in the explosive material and therefore more cesium-137 and strontium- 90 would be dispersed to the atmosphere than was projected in the EIS, which had considered only radionuclides external to the explosive. Calculations reviewed in the GAO report indicated dose 
consequences could be one tot two orders of magnitude higher than projected in the EIS when aerosolization of cesium and strontium in the explosive material was accounted for.

Dose assessments made in the GAO report (Peach 1990) were based on the assumption that a TNT-like detonation took place in a ferrocyanide layer in a tank. In this respect the GAO analysis followed Burger's (Burger 1984) "worst case" scenario that formed the basis for the explosion accident in the EIS (DOE 1987). Like Burger, the GAO report called for studies to better characterize ferrocyanide waste so that the probability of an explosive reaction could be quantified.

\subsection{DECLARATION OF FERROCYANIDE UNREVIEWED SAFETY QUESTION (USQ)*}

In October 1990, the hazard posed by uncontrolled exothermic reactions in ferrocyanide tanks was reviewed by Westinghouse Hanford Company (WHC) (Deaton 1990). WHC declared this hazard to be an unreviewed safety question (USQ) because the safety envelope for these tanks might not be bounded by the then-existing safety analysis report (Bergmann 1986) or by the 1987 EIS (DOE 1987).

In response to the USQ designation, studies were initiated to better understand the hazard to determine whether: (1) the existing safety envelope adequately bounds the hazard; or (2) a larger, but acceptable (from a risk standpoint) safety envelope was appropriate; or (3) the risk posed by the hazard was unacceptable and required mitigation.

These studies were carried out by a number of groups within the DOE community. Noteworthy milestones along the path to understanding the ferrocyanide safety issue are summarized in subsequent sections of this report.

*The USQ designation is a formal procedure required under specific orders from DOE (DOE 1986; DOE 1991). The USQ orders state, "A proposed change, test or experiment shall abe deemed to involve an unreviewed safety question if:

- The probability of occurrence or the consequences of an accident or malfunction of equipment important to safety, evaluated previously by safety analysis will be significantly increased, or

- A possibility for an accident or malfunction of a different type than any evaluation previously by safety analysis will be created which could result in significant safety consequences. 


\subsection{REVIEW OF FERROCYANIDE SAFETY STUDIES}

A number of documented reviews of the ferrocyanide issue were conducted to provide a current assessment of the issue and to identify information needed to resolve the issue. This work has provided a much-improved understanding of the properties of the ferrocyanide sludge, of the conditions necessary for it to react, and of the propagation velocity of such a reaction. These reviews are summarized as follows.

\subsection{IDENTIFICATION OF FERROCYANIDE TANKS}

Nguyen (1989) used a Hanford Site computer program, Track Radioactive Components (TRAC) (Jungfleisch 1984), and process information documented by Burger (1984) to identify tanks that contained as much as 1,000 gram-moles ( $\mathrm{g}$-moles) of ferrocyanides. The TRAC code was developed at the Hanford Site to track waste processing and transfer records and thus allow waste compositions in specific tanks to be estimated.

Nguyen (1989) identified 22 tanks that contained as much as 1,000 g-moles of ferrocyanides. The largest inventory in any tank was estimated at 100,000 to 200,000 g-moles, and was in Tank 241-BY-104. Nguyen (1989) also summarized estimated heat loads and highest measured temperatures for the 22 tanks. The highest temperature, $57^{\circ} \mathrm{C}$, was also in Tank 241-BY-104. This maximum measured temperature was noted to be "...far below the lowest reaction temperature $\left[240^{\circ} \mathrm{C}\right]$ observed in preliminary testing...." A later more detailed review by Borsheim and Simpson (1991) identified two more tanks as having received ferrocyanide (for a total of 24), but also found no evidence that ferrocyanide had been added to six of the 22 tanks.

In a discussion of ferrocyanide concentrations in wastes, Nguyen (1989) states that the ferrocyanides would likely be found in relatively concentrated, thin layers within the solids, and that concentrations in the ferrocyanide layers could be much higher than the tank average. These qualitative statements were consistent with the "worst case" scenario of Burger (1984) and tended to reinforce the idea that concentrated ferrocyanide-nitrate deposits were present in ferrocyanide tanks.

\subsection{DOE TASK TEAM REVIEW OF GAO AND EIS ASSESSMENTS}

DOE commissioned a task team to investigate the differences in the doses projected by the EIS for a ferrocyanide explosion (DOE 1987) and by the GAO audit team (Peach 1990). Key findings of this team (Kress et al. 1990) were:

1. The higher doses projected in the GAO report were based on Cs-137 being contained in the explosive solids, as opposed to being contained in inert solids external to the explosive solids as had been assumed in the EIS. 
2. The task team agreed with the GAO report that doses would be higher than projected in the EIS if the postulated vigorous explosion actually occurred.

3. The risk (probability times consequences) of a ferrocyanide explosion was low because the probability of an explosion was low.

4. Near-term efforts on resolving the ferrocyanide issue should emphasize work to determine the probability that an explosion could actually occur.

5. The fraction of waste that could be aerosolized by an explosion needs additional study because available data did not bear on the issue.

The conclusions and recommendation made by this Task Team guided work performed by DOE contractors to resolve the Ferrocyanide Safety Issue.

\subsection{REVIEW OF SINGLE-SHELL TANK WASTE STABILITY}

A review of chemical reaction hazards in single-shell waste tanks, which describes the processes by which ferrocyanide sludges were created, was published in 1991 (Borsheim and Kirch 1991). Ferrocyanide concentrations in waste were unknown at this time, and it was therefore assumed that uncontrolled reactions could be avoided only by maintaining waste temperatures well below reaction onset temperatures. A study of waste temperatures in BY-farm tanks showed that temperatures had declined significantly since 1975 . The higher temperatures experienced earlier were caused by the addition of hot, concentrated slurries originating from in-tank solidification processes carried out in the late $60 \mathrm{~s}$ and early $70 \mathrm{~s}$. The fact that temperatures cooled when hot waste was no longer added was evidence that heat dissipation by passive processes was adequate to maintain wastes at temperatures far below the onset of the ferrocyanide-nitrate reaction. The highest measured temperature $\left(57^{\circ} \mathrm{C}\right)$ was far below the cited reaction onset temperatures, which ranged from $220{ }^{\circ} \mathrm{C}$ to $325^{\circ} \mathrm{C}$ depending on the chemical composition of reactants.

The issue of "hot spots" was briefly addressed by Borsheim and Kirch (1991). Based on a review of sludge settling rates, it was concluded that sludge would likely exist in horizontal layers in tanks, but no mechanism could be identified that would cause radionuclides to concentrate in the small volume that would be required to reach the reaction onset temperature.

Two important conclusions cited in this study were:

1. Storage safety can be achieved by the waste temperature below the initiation point of a runaway exothermic reaction; and

2. In-tank temperatures are low, and have been stable or decreasing for years. 


\subsection{WESTINGHOUSE HANFORD COMPANY AEROSOL EXPERTS PANEL REVIEWS}

A panel of aerosol experts was assembled to advise WHC regarding a program designed to provide data on waste aerosolization that would result from a ferrocyanide explosion. The aerosol studies were to provide data cited as lacking in the GAO report (Section 3.6.1) and by the DOE Task Team (Section 4.2).

Two meetings of the WHC aerosol experts team were held at WHC, and key findings are summarized in Sections 4.4.1 and 4.4.2.

\subsubsection{Meeting of December 18, 1990}

Conclusions and summary statements that characterize discussions of the aerosol experts team at this meeting are as follows (Postma et al. 1991).

- The fraction of waste dispersed as an aerosol by a ferrocyanide-nitrate reaction is likely to vary with propagation velocity. For slow burns $(<1$ centimeter per second [ $\mathrm{cm} / \mathrm{sec}])$, relatively little waste would be aerosolized and escape from a tank. For fast burns, which in the limit is a detonation, the fraction aerosolized could be higher. Therefore, realistic assessments of aerosol behavior can be made only if the energetics and kinetics of ferrocyanide-nitrate reactions in waste are known.

- Proposed aerosol tests in the Containment System Test Facility at the Hanford Site could provide much-needed data to help assess the consequences of postulated ferrocyanide-nitrate reactions. The tests should be conducted under conditions that are as close as possible to waste tank conditions.

- The probability that a detonation could occur in ferrocyanide waste appeared to be very low because of diluents that reduce the reaction energy density. Therefore, the slow burn scenario was judged to be more likely than the detonation case. The team supported ongoing efforts to better characterize the ferrocyanide distribution in waste tanks with the idea that better knowledge would allow one to ascribe a negligible probability to a ferrocyanide detonation event.

\subsubsection{Meeting of March 2, 1992}

An enlarged panel of aerosol experts (Postma et al. 1992a, Deichman 1992) considered information developed by WHC during the 14 months that had elapsed since the first meeting. Topics considered are summarized as follows. 
Whereas the reaction scenarios considered in the first meeting included detonations that could cause gross tank failure, the second meeting focused on aerosol generation scenarios involving relatively slow reactions (propagation velocities in the neighborhood of $1 \mathrm{~cm} / \mathrm{s}$ ) in limited quantities of waste. This narrowing of focus resulted from studies of reaction phenomenology and waste characterization, which indicated that explosive reactions involving a large fraction of ferrocyanides in a tank were extremely improbable.

The experts considered aerosol behavior on the basis of a postulated ferrocyanide reaction. No consideration was given to the probability that such an event could actually occur. Starting with this assumption, the panel recommended tests with waste simulants to obtain the following data:

- the mass fraction aerosolized, including total mass, cesium, and strontium

- particle size and density

- generation rate of gases.

This information, obtained in pilot-scale tests, could be used with an aerosol code to analyze postulated tank reactions.

The panel concurred with the idea that aerosol-producing scenarios should focus on postulated hot spots. This scenario appeared to be more appropriate than earlier ones dealing with high velocity reactions consuming substantially all of the ferrocyanide in a tank. The panel also concluded that an in-depth technical analysis of the hot-spot issue would be required.

\subsection{REPORT OF HIGH-LEVEL WASTE TANKS ADVISORY PANEL}

A report issued by the DOE Tanks Advisory Panel (TAP) (Kazimi et al. 1992) described a systematic approach for classifying the hazard posed by ferrocyanide wastes.

The classification of waste into applicable safety categories helps determine the kinds of information needed to assess risk. For example, for waste in the INHERENT SAFETY and PASSIVE SAFETY categories (Kazimi et al. 1992), propagating chemical reactions can be ruled out, so consequence assessments are not needed. For the CONTROLLED SAFETY category, wastes are reactive and an accident is prevented by the exclusion of an initiator. The CONTROLLED CONSEQUENCES category class covers the case where an accident is possible, and risk is limited by controlling consequences. 
Ranking of ferrocyanide waste into one of these safety categories requires two kinds of information:

1. Criteria that define the composition boundaries for reactive versus non-reactive wastes.

2. Actual compositions of waste in ferrocyanide tanks.

A qualitative evaluation of available information on 1 and 2 above (Kazimi et al. 1992) led the TAP to conclude: "The present observations tend to support the conclusion that a large ferrocyanide-nitrate explosion is unlikely under existing tank conditions. In realizing this passive safety state, the primary safety mechanism is the dilution of the ferrocyanides with "inerts" so that chemical reactions cannot propagate." This tentative assessment of current safety was qualified by another conclusion of the TAP: "If passive and controlled safety cannot be clearly demonstrated for all tanks, understanding of potential accidents and their effects is required. To obtain reliable estimates of the consequences of a ferrocyanide-nitrate explosion, experiments will be required to determine aerosol particulate size from the range of possible accident conditions."

This assessment by the TAP considered both the probability and consequence of ferrocyanide-nitrate reactions, whereas the earlier assessments in the EIS and the GAO audit report dealt with consequences without considering the probability that an explosion could actually occur. An important feature of the safety category approach outlined by the TAP report (Kazimi et al. 1992) is that it helps identify hazards where consequence evaluation is useful. For ferrocyanide waste falling into the INHERENT or PASSIVE safety categories, propagating chemical reactions can be ruled out.

\subsection{WESTINGHOUSE HANFORD COMPANY HAZARDS ANALYSIS REPORT}

An analysis of the hazards of storing ferrocyanide waste (Grigsby et al. 1992) brought together information on waste composition, storage conditions and hazards related to uncontrolled ferrocyanide-nitrate/nitrite reactions. Key results of this study are summarized as follows.

\subsubsection{Moisture Retention of Ferrocyanide Waste}

Based on the physical and chemical properties of ferrocyanide waste, it was projected that water contents would remain high (approximately $40 \mathrm{wt} \%$ ) after drainable water was pumped out. Also, the loss of water by evaporation into headspace air was shown to be negligible for the ferrocyanide tanks, which are all passively ventilated. 


\subsubsection{Compositional Limits for Propagating Reactions}

A conservative thermodynamic energy balance model was derived to predict ferrocyanide concentrations that differentiated propagating reactions from those which would not propagate. The range of best-estimate compositions of tank sludge (Ferrocyanide and water) fell well below the propagating limit line. The implication was that much of the ferrocyanide waste in underground tanks would be too dilute to support a propagating reaction.

\subsubsection{Cesium Distribution in Waste Tanks}

Mapping of radiation levels as a function of height in the waste indicated that cesium was distributed throughout the entire sludge layer. This result implies that ferrocyanides are also distributed over a thick layer and are not present in pure form in a thin layer, as had been pictured in earlier studies.

\subsubsection{Flowsheets for Ferrocyanide Sludge}

Based on a study of processing records, it was determined that three flowsheets, and variations on them, were used to decontaminate aqueous wastes. Simulated sludges were prepared following these flowsheets, and their compositions and properties were measured (Jeppson and Wong 1993).

\subsection{CURRENT UNDERSTANDING SNAPSHOT - NOVEMBER 1991}

A review of information related to storage safety (Postma et al. 1992b) provided a snapshot in time of (1) what was known about ferrocyanide waste stored in underground tanks at the Hanford Site; (2) what this information meant in terms of storage safety; (3) what key uncertainties existed; and (4) what needed to be done to resolve uncertainties.

Quoting from the summary (Section 1.0) of Postma et al. (1992b), findings are summarized as follows: "Based on data to date, a preliminary conclusion is that most (if not all) of the tanks contain waste that is nonreactive in its present form. Studies indicate that significant dryout can be prevented, thus keeping waste forms nonreactive. However, additional information is needed to confirm these initial conclusions and to develop surveillance and control systems. Of particular importance is the need to (1) sample tanks to characterize the waste; (2) conduct laboratory studies on real waste; and (3) continue to test simulants to better define physical and chemical properties of stored waste."

The preliminary conclusion that most (if not all) tanks contained waste that would not support a propagating reaction, supports the idea that explosive, worst-case accidents analyzed in earlier studies (Burger 1984, DOE 1987, Peach 1990) are very low probability sequences that may not be meaningful in assessing the risk posed by ferrocyanide waste. 


\subsection{RESEARCH STUDIES}

This section briefly reviews research studies that bear on the issue of uncontrolled exothermic reactions in ferrocyanide waste. One major objective is to show how recent work has helped to determine waste compositions for which an explosive reaction can be ruled out.

\subsubsection{Westinghouse Hanford Company Studies}

4.8.1.1 Study of Process Records. Historical process records have been used to identify the flowsheet used to prepare each batch of ferrocyanide sludge and to trace its transfer in the tank farms (Borsheim and Simpson 1991, Jeppson and Wong 1993). These estimates of ferrocyanide inventories are much more reliable than the older TRAC (Jungfleisch 1984) records. This information, together with measured compositions of simulant sludges, has allowed ferrocyanide inventories and concentrations to be predicted for each ferrocyanide Watch List tank. Predicted concentrations varied from $3.5 \mathrm{wt} \%$ to $24.2 \mathrm{wt} \%$ on a dry basis (Postma et al. 1994) under the assumption that no degradation of ferrocyanides had occurred during the years of storage. The sludges with the highest concentrations were predicted to reside in C-Farm tanks; this sludge was produced by the In-Farm flowsheet.

4.8.1.2 Preparation of Simulant Sludges. Simulant sludges were prepared according to the three flowsheets used at the Hanford Site. Ferrocyanide concentrations (cyanide expressed as sodium nickel ferrocyanide) varied from $4.6 \mathrm{wt} \%$ to $25.5 \mathrm{wt} \%$ on dried samples (Jeppson and Simpson 1994, Postma et al. 1994). The In-Farm flowsheets produced sludges having the higher ferrocyanide concentration, whereas the U-Plant flowsheets produced sludge having the lower ferrocyanide concentrations. All of the sludges retained relatively high moisture contents (35 wt\% to $69 \mathrm{wt} \%$ ) after centrifuging for a time that corresponded to a gravity-time product of 30 years (Postma et al. 1994).

4.8.1.3 Core Sampling of Tanks. Core samples have been taken from multiple locations in several ferrocyanide tanks. The samples were divided into vertical segments to determine how composition varied with depth. Differential scanning calorimetry (DSC) was used to measure the exothermic heat release from reaction of dry sludge. The results are given below in Table 4-1.

Even the maximum exotherms measured in samples from the ferrocyanide tanks are far below the critical value of $1,200 \mathrm{~J} / \mathrm{g}$ required to support a propagating reaction (Fauske and Epstein 1995). It is worth noting that the sampled tanks include the only four tanks which contained In-Farm sludge, which was the most concentrated in ferrocyanide of any added to the Hanford waste tanks. The very low measured exotherms together with the aging studies discussed in Section 4.8.3.2 strongly suggest that the ferrocyanide in all tanks has been destroyed by aging to well below any concentration of concern. 
Table 4-1. Exotherms of Tank Samples.

\begin{tabular}{|l|c|c|l|}
\hline \multicolumn{1}{|c|}{ Tank } & Flow Sheet & DSC Exotherms, J/g & \multicolumn{1}{|c|}{ Reference } \\
\hline C-108 & In-Farm & 0 to 109 & Cash et al. 1995 \\
\hline C-109 & In-Farm & 0 to 52 & Simpson et al. 1993b \\
\hline C-111 & In-Farm & all 0 & Meacham et al. 1995 \\
\hline C-112 & In-Farm & 17 to 38 & Simpson et al. 1993a \\
\hline T-107 & U-Plant & All 0 & Sasaki and Valenzuela 1994 \\
\hline TY-104 & T-Plant & All 0 & Cash et al. 1995 \\
\hline
\end{tabular}

Samples from tank BY-106 showed DSC exotherms of $670,1,400$, and $670 \mathrm{~J} / \mathrm{g}$. However, the analyses for ferrocyanide and for total organic carbon showed that this fuel value is from organics not from ferrocyanide (Meacham et al. 1995).

4.8.1.4 Decay Heat Dissipation in Ferrocyanide Tanks. The degree to which waste can self-heat depends on the rate at which heat is generated by radioactive decay. Recent studies of decay heat loads in ferrocyanide tanks (Crowe et al. 1993, McLaren 1993, 1994a, 1994b) have permitted heat loads to be estimated from a first-principles heat transfer model. Based on this model, heat loads are predicted to be 3 kilowatts or less for all Ferrocyanide Watch List tanks. Because heat loads are this low, self-heating of waste is quite limited. The following statements (Postma et al. 1994) summarize conclusions regarding decay heat dissipation.

- The decay heat loads in all ferrocyanide tanks are relatively low, being only a few kilowatts.

- Heat removal is entirely by passive mechanisms and does not rely significantly on evaporative cooling.

- The resulting sludge temperatures are low, all being no greater than $53{ }^{\circ} \mathrm{C}$, and are decreasing. Data from the eight ferrocyanide tanks that have two thermocouple trees do not suggest large lateral temperature variations (Meacham, Cash, and Dukelow 1995).

\subsubsection{Reaction Studies at Fauske and Associates, Inc.}

4.8.2.1 Composition Limits on Reactivity. Experimental and theoretical studies have been conducted at Fauske and Associates, Inc. (FAI) to characterize conditions under which reaction propagation is possible. 
Adiabatic calorimetry test results indicate that for dry mixtures, propagating-type reactions can occur at ferrocyanide concentrations greater than $14 \mathrm{wt} \% \mathrm{Na}_{2} \mathrm{NiFe}(\mathrm{CN})_{6}$ (Meacham et al. 1994). Propagation tests of the simulant with the highest ferrocyanide concentration [In-Farm flowsheet having $25.5 \mathrm{wt} \% \mathrm{Na}_{2} \mathrm{NiFe}\left(\mathrm{CN}_{6}\right)$ ] showed that a freemoisture content of $12 \mathrm{wt} \%$ was sufficient to prevent reaction propagation for this highest concentration simulant waste (Fauske 1992).

Theoretical studies on reaction propagation (Epstein et al. 1994, Fauske 1993a, Fauske 1993b) identified a critical ferrocyanide concentration of approximately $15 \mathrm{wt} \%$ $\mathrm{Na}_{2} \mathrm{NiFe}(\mathrm{CN})_{6}$ for propagation in dry mixtures. A free-moisture content of approximately $12 \mathrm{wt} \%$ was predicted to prevent propagation in mixtures of reactants that contained $26 \mathrm{wt} \%$ $\mathrm{Na}_{2} \mathrm{NiFe}(\mathrm{CN})_{6}$ on a dry basis. These theoretical predictions are in good agreement with the experimental test results described in the previous paragraph.

4.8.2.2 Velocity of a Propagating Reaction in Ferrocyanide Sludge. The linear velocity at which a chemical reaction can propagate through ferrocyanide sludge, given conditions under which such a reaction is possible at all, is of importance in determining the consequences of a ferrocyanide reaction. In general, the propagation velocities of chemical reactions can range over several orders of magnitude from thousands of meters per second, characteristic of detonations, to very slow, smoldering reactions.

The propagation velocity of simulant In-Farm ferrocyanide sludge has been measured by Fauske (1993a). (The U-Plant and T-Plant sludges are too diluted to support a propagating reaction, even if dry.) Fauske's test apparatus consists of a thin, insulated, stainless steel cylinder 25 millimeters $(\mathrm{mm})$ in diameter and $100 \mathrm{~mm}$ tall, open at the top and filled with the test material. The reaction is ignited at the top by a $\mathrm{BaO}_{2}-\mathrm{Al}$ mixture. The progress of the reaction is monitored by four thermocouples spaced 20 or $30 \mathrm{~mm}$ apart vertically.

The conditions and results of the propagation velocity measurements are tabulated below in Table 4-2. Propagation velocities ranged from 5 to 32 centimeters per minute $(\mathrm{cm} / \mathrm{min})$. A reaction this slow may be considered as a burn rather than an explosion.

Table 4-2. Measurements of Propagation Velocity.

\begin{tabular}{|c|c|c|c|c|}
\hline $\begin{array}{c}\text { Initial temperature } \\
\left({ }^{\circ} \mathrm{C}\right)\end{array}$ & $\begin{array}{c}\text { Absolute } \\
\text { Pressure (atm) }\end{array}$ & $\begin{array}{c}\text { Free moisture } \\
\left(\% \mathrm{H}_{2} \mathrm{O}\right)\end{array}$ & $\begin{array}{c}\text { Burn Velocity } \\
(\mathrm{cm} / \mathrm{min})\end{array}$ & Reference \\
\hline 26 & 1 & 0 & 10 & Fauske 1992 \\
\hline 26 & 1 & 8 & 5.3 & Fauske 1992 \\
\hline 60 & 3 & 1 & 12.6 & Fauske 1993c \\
\hline 60 & 10 & 0 & 16 & Fauske 1993d \\
\hline 60 & 53 & 0 & 32 & Fauske 1993c \\
\hline 120 & 3 & 1 & 20.4 & Fauske 1993c \\
\hline
\end{tabular}


4.8.2.3 Ignition Requirements. A theoretical study by Epstein and Fauske (1993) considered the requirements for the initiation of self-propagating reactions from small volumes heated to high temperatures. Use was made of a numerical computer code to solve the equations of thermal conduction with temperature-dependent heat generation. It was concluded that hot spots will not lead to self-propagation reactions in ferrocyanide mixtures that exhibit Arrhenius self-heat behavior (i.e., in dried material from the U-Plant or T-Plant flowsheets). In mixtures that exhibit highly exothermic temperature-independent kinetics (i.e., dried sludge from the In-Farm flowsheet), self-propagating reactions are possible only when the hot spot can raise the temperature of adjacent unreacted material above its ignition temperature.

4.8.2.4 Dryout of Ferrocyanide Sludge. If the ferrocyanide sludge retains sufficient moisture, an energetic chemical reaction will not be possible. Therefore, an extensive study was made by FAI and WHC to determine whether any credible process could lead to dryout (Epstein et al. 1994). The findings are summarized below.

- All waste temperatures are below $54{ }^{\circ} \mathrm{C}$ and falling as heat-producing radionuclides decay. Heat removal is entirely by passive processes, so no failure can give impaired heat removal and thus lead to higher temperatures.

- All ferrocyanide tanks are passively ventilated and net water loss by evaporation is too low to remove more than small fraction of the water in 30 years. Any such water loss would be uniform throughout the sludge, not in a surface layer.

- Some water loss could occur through a tank leak or pumping. However, this loss would be distributed uniformly over the sludge volume and would not reduce the water content sufficiently to permit the sludge to become reactive.

- Dryout cannot result from boiling off of water from an internal hot spot.

1. The concentration of radionuclides required to even reach the boiling point is too great to be credible.

2. Tests were conducted that show that water would be wicked in faster than it could boil off.

3. Other tests showed that boiling would produce steam bubbles, not dried sludge.

- Local high rates of surface evaporation from possible warm regions on the surface would not cause dryout, because tests showed that the water would be wicked to the sludge surface much faster than it could evaporate. 


\subsubsection{Pacific Northwest Laboratory Studies}

4.8.3.1 Ferrocyanide - Nitrate/Nitrite Reaction Phenomenology. Laboratory studies at PNL used three experimental methods to study reaction onset temperature: differential scanning calorimetry; scanning thermogravimetry; and time-to-explosion tests (Burger and Scheele 1991). These tests, done with reactants that were relatively pure and dry, yielded reaction start temperatures of $220^{\circ} \mathrm{C}$ to $280{ }^{\circ} \mathrm{C}$ and critical temperatures for explosive reactions ranging from $280{ }^{\circ} \mathrm{C}$ to $370{ }^{\circ} \mathrm{C}$, depending on composition of the sample tested.

Based on a review of the chemistry of the ferrocyanide scavenging process, several ferrocyanide species were identified as probable precipitated species. Sodium nickel ferrocyanide was identified as the principle precipitated form (Scheele et al. 1991). The effects of possible catalysts, or initiators on reaction initiation temperature were shown to be relatively minor (Scheele et al. 1993).

Dynamic X-ray diffraction studies of the reaction between $\mathrm{Na}_{2} \mathrm{NiFe}(\mathrm{CN})_{6}$ and equimolar concentrations of sodium nitrate/nitrite (Dodds and Thomson 1994) indicated that endothermic dehydration and melting of nitrates took place before the occurrence of exothermic reactions at about $300{ }^{\circ} \mathrm{C}$. Comparisons of the estimated heat release rate with heat transfer rates from a hypothetical $1.0-\mathrm{ft}^{3}$ hot spot showed that, even in the worst-case scenario, the heat transfer rates are roughly an order of magnitude higher than the rate of energy release from the exothermic reactions.

4.8.3.2 Aging of Ferrocyanide Sludge. Measurements have been made, and are continuing, of the rate at which sodium nickel ferrocyanide is destroyed by aging reactions as a function of radiation, temperature, and pH (Babad et al. 1993, Lilga et al. 1993, 1994). These data suggest that the ferrocyanide added 38 or more years ago would have been largely destroyed by now. This would explain the low ferrocyanide concentrations measured in the tank samples discussed in Section 4.8.1.3.

4.8.3.3 Hot Spot Formation by In-Tank Convection. One postulated mechanism for the formation of a hot spot in ferrocyanide tanks is sorption/desorption from the convective flow of interstitial liquor within the sludge. Computational analyses of this phenomenon (McGrail et al. 1993) have shown that the cesium redistributions within the tank that could be produced by this mechanism would be of minor importance; peak waste temperatures were predicted to increase by roughly $5^{\circ} \mathrm{C}$, an increase too small for such hot spots to pose a credible dryout or ignition source.

\subsubsection{Los Alamos National Laboratory Studies}

4.8.4.1 Evaluation of Explosion Hazard. Tests on ferrocyanide wastes to evaluate their explosive hazard (Cady 1992) showed that the mixtures were not ignited by mechanical insult (standard impact and friction sensitivity tests), and that they required an external heat source before any exothermic chemical reaction could be observed. Thermal tests indicated 
significant exothermic reactions were initiated after melting endotherms that were evident above approximately $220^{\circ} \mathrm{C}$. Major exotherms were evident at temperatures above approximately $260^{\circ} \mathrm{C}$.

4.8.4.2 Preliminary Explosion Calculations. Preliminary analyses were carried out at Los Alamos National Laboratory to assess a worst-case explosion in tank 241-BY-104 (Eisenhawer 1991).

Key assumptions on which the analysis was based include the following.

- Ferrocyanide had settled into a layer $76 \mathrm{~cm}$ thick in tank 241-BY-104

- A 76-cm-diameter (437-kilogram) sphere was dried, heated by decay heat, and underwent a detonation

- Detonation propagation velocity was 4,000 meters per second

- Energy density was $1 \mathrm{~kJ} / \mathrm{gram}$.

If a highly explosive reaction involving this amount of ferrocyanide could in fact occur, the following results were predicted. This postulated explosion was predicted to aerosolize approximately 30,000 kilograms of waste, of which 1,500 kilograms was in the respirable size range $(<10$ micrometers $[\mu \mathrm{m}]$ diameter). The tank was assumed to remain largely intact as a result of this explosion. An estimated $6 \%$ of the cesium inventory in the tank was indicated to become aerosolized, primarily by vaporization, into particles that were initially smaller than $10 \mu \mathrm{m}$ in diameter. Aerosol leakage from the tank was not quantified in this preliminary analysis.

\subsection{FAILURE LIMITS OF WASTE TANKS}

The internal pressure that the waste tanks can withstand without failure is a significant parameter defining the consequences of an energetic chemical reaction. The static internal pressure capacity of Hanford Site single-shell waste tanks has been calculated by ADVENT Engineering Services (Baliga et al. 1994). The one-million-gallon tank and the half-million-gallon tanks were found to withstand internal pressures of 11.6 and 14 pounds per square inch gauge, respectively. Beyond these pressures, the rebar stress increases rapidly with the application of small pressure increments. The report states that these two analyses are expected to bound the 750,000-gallon tanks. 


\subsection{DEFINITION OF SAFETY CRITERIA}

Criteria that can be used to judge the hazard posed by sustained, rapid exothermic reactions between ferrocyanides and nitrate/nitrite salts in stored wastes were published in January 1994 (Postma et al. 1994). Three safety categories were formulated on the basis of answers to two safety questions: (1) is a significant exothermic reaction possible during interim storage? and (2) is a significant exothermic reaction possible under present conditions of waste moisture content? A significant reaction is one that generates heat faster than it can be removed by conduction. Waste that meets the safety objective cannot sustain a propagating reaction and therefore could not burn, or explode.

The hazard potentials for exothermic reactions in ferrocyanide waste were classified in three levels as follows:

\section{Level 1 - SAFE}

Concentration of fuel $\leq 8 \mathrm{wt} \%$ sodium nickel ferrocyanide*

Concentration of water - not limiting

Concentration of oxidizers - not limiting

Temperature of waste - not limiting

\section{Level 2 - CONDITIONALLY SAFE}

Concentration of fuel $>8 \mathrm{wt} \%$ sodium nickel ferrocyanide

Concentration of water $\geq 0$ to $24 \mathrm{wt} \%{ }^{* *}$

Concentration of oxidizers - not limiting

Temperature of waste $\leq 90^{\circ} \mathrm{C}^{* * *}$

\section{Level 3 - UNSAFE}

Criteria for SAFE and CONDITIONALLY SAFE are not met.

For tanks that fall into the SAFE category, assurance of low fuel content is sufficient to address the ferrocyanide hazard during interim storage. For CONDITIONALLY SAFE tanks, assurance on minimum retained moisture and maximum waste temperature is required. For tanks that are assigned to the UNSAFE category, monitoring and controls are required to avoid conditions that could lead to reaction initiation. A modification in the waste state is required to remove a tank from the UNSAFE category.

${ }^{*} \mathrm{Na}_{2} \mathrm{NiFe}(\mathrm{CN})_{6}$ on an energy equivalent basis, calculated on a zero free water basis.

**Free water content. The moisture criterion increases linearly from 0 percent at $8 \mathrm{wt} \%$ fuel to $24 \mathrm{wt} \%$ at $26 \mathrm{wt} \%$ fuel.

-..Temperature is not an independent criterion; it is implicit in the moisture criterion. 
Based on comparison of current knowledge of tank contents with the safety criteria, two ferrocyanide tanks were put into the SAFE category and the remainder were put into the CONDITIONALLY SAFE category. No tanks fit the UNSAFE category. The ranking was done on the basis of a conservative interpretation of available data.

\subsection{CLOSURE OF USQ}

The ferrocyanide USQ was closed by DOE in March 1994 (Sheridan 1994). The closure was approved by DOE on the safety basis provided in "Ferrocyanide Safety Program: Safety Criteria for Ferrocyanide Watch List Tanks" (Postma et al. 1994), and Program Secretarial Officer approval in accordance with DOE Order 5480.21 (DOE 1991).

Closure of the ferrocyanide USQ is not the same as resolution of the Ferrocyanide Safety Issue. 


\subsection{CURRENT UNDERSTANDING OF THE SAFETY OF FERROCYANIDE WASTE}

\subsection{SUMMARY OF IMPORTANT RESULTS OF FERROCYANIDE STUDIES}

Early work on the possible consequences of a postulated ferrocyanide reaction made extremely conservative assumptions in the absence of reliable information. These assumptions included stoichiometric mixtures of undiluted ferrocyanide and oxidant, all or a large fraction of the ferrocyanide inventory dry and reactive, a detonation or a TNT-like explosive reaction, and ignition by internal hot spots resulting from decay heating. The results of the many ferrocyanide studies summarized above have provided a much clearer picture of the nature of and limits on possible ferrocyanide reactions than had previously been available. The important results of these studies may be summarized as follows:

- The ferrocyanide sludges in the waste tanks contain large amounts of diluents in addition to the ferrocyanide and oxidants. The compositions of the ferrocyanide sludges added to the tanks have been determined by replication of the flowsheet processes used to generate the original sludge.

- The range of compositions of ferrocyanide sludge capable of sustaining a propagating chemical reaction has been established by experimental measurement supported by theoretical considerations. Dry sludge with an excess of nitrate/nitrite must contain at least $15 \mathrm{wt} \% \mathrm{Na}_{2} \mathrm{Ni}(\mathrm{FeCN})_{6}$ to be reactive. The required fuel content increases with water content, and $12 \mathrm{wt} \%$ water will prevent a propagating reaction for the highest flowsheet concentration (26 wt\% $\left.\mathrm{Na}_{2} \mathrm{NiFe}(\mathrm{CN})_{6}\right)$.

- Sodium nickel ferrocyanide in the presence of nitrate or nitrite salts is subject to slow degradation and destruction by aging reactions. These reactions are enhanced by radiation, elevated temperatures, and high $\mathrm{pH}$. The experimental data on aging strongly suggest that most of the ferrocyanide would have been destroyed during 38 years of storage and that present ferrocyanide concentrations are negligibly small. This conclusion is supported by analyses of tank core samples available to date. A final conclusion must await completion of aging studies and analysis of samples from additional tanks.

- The ferrocyanide sludge in the waste tanks is wet and will stay wet. Dryout by pumping, leakage, hot spots, and surface evaporation has been considered and found to be negligible.

- The measured velocity of propagation of a ferrocyanide reaction is on the order of a few millimeters per second. Analogy to an explosive is false. 
- Ignition of a reaction would be difficult and unlikely, even if fuel and moisture concentrations permitted it. Ferrocyanide sludge cannot be ignited by mechanical shock; an elevated temperature (about $250^{\circ} \mathrm{C}$ ) is required. All ferrocyanide tank temperatures are well below this, heat removal is entirely by passive mechanisms, and there are no mechanisms to concentrate decay heat sufficiently to reach the ignition temperature.

\subsection{PRESENT NEED FOR CONSEQUENCE ANALYSIS AND AEROSOL TESTS}

The present understanding of the ferrocyanide problem has greatly reduced the need for detailed analyses of the consequences of possible chemical reactions and of aerosol testing in support of such analyses.

- An energetic chemical reaction of the ferrocyanide is now viewed as not credible. This conclusion results from the findings that: (1) high enough concentrations of ferrocyanide no longer exist after 38 years of aging to support a reaction even if dry; (2) the ferrocyanide sludge is too wet to permit a chemical reaction even at high ferrocyanide concentrations and cannot dry out enough by any mechanism to become so; and (3) ignition would be very difficult, because waste temperatures are far below the ignition temperature and cooling is entirely by passive means. Any one of these three conditions would preclude a reaction. It is expected that the ferrocyanide issue can be resolved in the near future by showing that a vigorous reaction is not credible, although the measurements, analyses, and documentation to demonstrate this are not yet complete.

- Analyses of the consequences of a ferrocyanide reaction are not needed if such a reaction is not credible. If the probability is zero, the risk is zero regardless of consequences. Furthermore, a realistic consequence analysis is not possible. Credible parameters defining the event (e.g., fuel concentration; amount of dried ferrocyanide) cannot be input to such an analysis when credible values give no reaction.

- The proposed aerosol tests were in support of consequence analyses and are therefore not required if consequence analyses are not needed. Furthermore, the aerosol tests were proposed when it was thought that a ferrocyanide reaction might be explosive and generate aerosols primarily by mechanical break-up of the sludge. It is now known that the reaction propagation velocity is only a few millimeters per second and the reaction is too weak for efficient aerosol generation by mechanical means. Instead, aerosol generation would be dominated by vaporization and subsequent condensation of the volatile radionuclides, particularly of cesium compounds. This process may be predicted from thermodynamic principles, given the product temperature and volume of gas generated. Generation of aerosols by this process has been thoroughly 
studied in studies of melt-down accidents in nuclear reactors, and extensive computer codes are available to describe the aerosol behavior. Testing, although possibly useful, is not necessary.

- On the basis of the above considerations, the analysis of the consequences of postulated ferrocyanide reactions, and aerosol generation tests in support of such analyses, are no longer included in the scope of work in support of resolving the Ferrocyanide Issue in the Hanford Site waste tanks. 
WHC-EP-0876

This page intentionally left blank. 


\subsection{REFERENCES}

Babad, H., J. E. Meacham, B. C. Simpson, and R. J. Cash, 1993, The Role of Aging in Resolving the Ferrocyanide Safety Issue, WHC-EP-0599, Westinghouse Hanford Company, Richland, Washington.

Baliga, R., S. B. Kok, R. S. Marlow, C. J. Moore, and T. Y. Wang, 1994, Static Internal Pressure Capacity of Hanford Single-Shell Waste Tanks," WHC-SD-WM-TI-623, Westinghouse Hanford Company, Richland, Washington.

Bergmann, L. M., 1986, Single-Shell Isolation Safety Analysis Report, WHC-SD-WM-SAR-006, Rev. 2, Westinghouse Hanford Company, Richland, Washington.

Borsheim, G. L., and N. W. Kirch, 1991, Summary of Single-Shell Tank Waste Stability, WHC-EP-0347, Westinghouse Hanford Company, Richland, Washington.

Borsheim, G. L., and B. C. Simpson, 1991, An Assessment of the Inventories of the Ferrocyanide Watch List Tanks, WHC-SD-WM-ER-133, Rev. 0, Westinghouse Hanford Company, Richland, Washington.

Burger, L. L., 1984, Complexant Stability Investigation, Task 1, Ferrocyanide Solids, PNL-5441, Pacific Northwest Laboratory, Richland, Washington.

Burger, L. L., and R. D. Scheele, 1991, The Reactivity of Cesium Nickel Ferrocyanide Towards Nitrate and Nitrite Salts, PNL-7550, Pacific Northwest Laboratory, Richland, Washington.

Cady, H. H., 1992, Evaluation of Ferrocyanide/Nitrate Explosion Hazard, LA-12589-MS, Los Alamos National Laboratory, Los Alàmos, New Mexico.

Cash, R. J., J. E. Meacham. and G. T. Dukelow, 1995, Quarterly Report on the Ferrocyanide Safety Program for the Period Ending March 31, 1995, WHC-EP-0474-16, Westinghouse Hanford Company, Richland, Washington.

Crowe, R. D., M. Kummerer, and A. K. Postma, 1993, Ferrocyanide Safety Program: Estimate of Heat Load in Waste Tanks Using Average Vapor Space Temperature, WHC-EP-0709, Westinghouse Hanford Company, Richland, Washington.

Deaton, D. E., 1990, Unusual Occurrence-Unreviewed Safety Questions Regarding Tanks Containing Ferrocyanide, WHC-90-B003-R1, Update 10-22-90, Westinghouse Hanford Company, Richland, Washington. 
Deichman, J. L., 1992, Completion of Department of Energy, Richland, Field Office Milestone 2028: Aerosol Panel Recommendations, (letter 9251956 to R. E. Gerton, U.S. Department of Energy, March 30), Westinghouse Hanford Company, Richland, Washington.

Dodds, J. N., and W. J. Thomson, 1994, Ferrocyanide Safety Project Dynamic X-Ray Diffraction Studies of Sodium Nickel Ferrocyanide Reactions with Equimolar Nitrate/Nitrite Salts, PNL-10050, Pacific Northwest Laboratory, Richland, Washington.

DOE, 1986, Safety of Nuclear Facilities, DOE Order 5480.5, U.S. Department of Energy, Washington, D.C.

DOE, 1987, Final Environmental Impact Statement - Disposal of Hanford Defense High-Level, Transuranic, and Tank Wastes, Vols. 1-5, DOE/EIS-0113, U.S. Department of Energy, Washington, D.C.

DOE, 1991, Unreviewed Safety Questions, DOE Order 5480.21, U.S. Department of Energy, Washington, D.C.

Eisenhawer, S., 1991, Review of Aerosol Generation Experiments, Predecisional Draft, presented at Los Alamos, New Mexico, Los Alamos National laboratory, Los Alamos, New Mexico.

Epstein, M., and H. K. Fauske, 1993, FAI/93-106 Conditions for Reaction Propagation in Dried Ferrocyanide/Nitrate-Nitrite Powders, WHC-SD-WM-TI-619, Rev. 0, Westinghouse Hanford Company, Richland, Washington.

Epstein, M., H. K. Fauske, D. R. Dickinson, M. D. Crippen, J. D. McCormack, R. J. Cash, J. E. Meacham, and C. S. Simmons, 1994, Ferrocyanide Safety Program: An Assessment of the Possibility of Ferrocyanide Sludge Dryout, WHC-EP-0816, Westinghouse Hanford Company, Richland, Washington.

Fauske, H. K., and M. Epstein, 1955, The Contact Temperature Ignition (CTI) Criterion for Propagating Chemical Reactions Including the Effect of Moisture and Application to Hanford Waste, FAI/94-103(a), Fauske and Associates, Inc., Burr Ridge, Illinois.

Fauske, H. K., 1992, Adiabatic Calorimetry and Reaction Propagation Tests with Synthetic Ferrocyanide Materials Including U Plant 1, U Plant 2, In Farm 1, In Farm 2, and Vendor-Procured Sodium Nickel Ferrocyanide, WHC-SD-WM-RDT-054, Rev. 0, Westinghouse Hanford Company, Richland, Washington. 
Fauske, H. K., 1993a, Fuel Concentration Required for Deflagration of Ferrocyanide Mixtures, (memorandum to R. J. Cash, Westinghouse Hanford Company, September 14), Fauske and Associates, Inc., Burr Ridge, Illinois. (This memorandum is reproduced as Attachment B-3 of Appendix B, of WHC-EP-0691 [Postma et al. 1994].)

Fauske, H. K., 1993b, Propagation Tests with In Farm 1 Bottom Half Flow Sheet Material [ - 26 wt \% $\mathrm{Na}_{2} \mathrm{NiFe}(\mathrm{CN})_{6}$ - Dry Basis $\mathrm{Al}_{2} \mathrm{O}_{3}$ as a Diluent, (memorandum to R. J. Cash, Westinghouse Hanford Company, September 23. (This memorandum is reproduced as Attachment B-4 of Appendix B, of WHC-EP-0691 [Postma et al. 1994].)

Fauske, H. K., 1993c, Summary Report on Parametric Pressure Propagation Test T0127-1, WHC-EP-0661, Westinghouse Hanford Company, Richland, Washington.

Fauske, H. K., 1993d, Summary Report on 49L Ferrocyanide Aerosol Tests T0208-1 and T0-209-1, WHC-EP-0662, Westinghouse Hanford Company, Richland, Washington.

Grigsby, J. M., D. B. Bechtold, G. L. Borsheim, M. D. Crippen, D. R. Dickinson, G. L. Fox, D. W. Jeppson, M. Kummerer, J. M. McLaren, J. D. McCormack, A. Padilla, B. C. Simpson, and D. D. Stepnewski, 1992, Ferrocyanide Waste Tank Hazard Assessment - Interim Report, WHC-SD-WM-RPT-032, Rev. 1, Westinghouse Hanford Company, Richland, Washington.

Jeppson, D. W., and J. J. Wang, 1993, Ferrocyanide Waste Simulant Characterization, WHC-EP-0631, Westinghouse Hanford Company, Richland, Washington.

Jeppson, D. W., and B. C. Simpson, 1994, Characterization and Reaction Behavior of Ferrocyanide Simulants and Hanford Site High-Level Ferrocyanide Waste, WHC-SA-2190-FP, Westinghouse Hanford Company, Richland, Washington.

Jungfleisch, F. M., 1984, A Preliminary Estimation of the Waste Inventories in Hanford Tanks Through 1980, SD-WM-TI-057, Rockwell Hanford Operations, Richland, Washington.

Kazimi, M. S., C. S. Abrams, D. O. Campbell, F. N. Carlson, M. W. First, C. W. Forsberg, B. C. Hudson, T. S. Kress, T. E. Larson, D. T. Oakley, G. E. Schmauch, S. E. Slezak, and A. S. Veletsos, 1992, Approach to Resolution of Safety Issues Associated with Ferrocyanides in the Hanford Waste Tanks, High-Level Waste Tanks Advisory Panel, U.S. Department of Energy, Washington, D.C.

Kress, T., K. Bandyopudhyay, P. d'Entremont, S. Slezak, and M. Reich, 1990, Risk of a Ferrocyanide Explosion in the Hanford Waste Tank Farm, (memorandum to John Tseng, U.S. Department of Energy, September 20), Oak Ridge National Laboratory, Oak Ridge, Tennessee. 
Lilga, M. A., M. R. Lumetta, and G. F. Schiefelbein, 1993, Ferrocyanide Safety Project, Task 3, Ferrocyanide Aging Studies, FY 1993 Annual Report, PNL-8888, Pacific Northwest Laboratory, Richland, Washington.

Lilga, M. A., E. V. Alderson, D. J. Kowalski, M. R. Lumetta, and G. F. Schiefelbein, 1994, Ferrocyanide Safety Project, Tasks, Aging Studies, FY 1994 Annual Report, PNL-10126, Pacific Northwest Laboratory, Richland, Washington.

McGrail, B. P., D. S. Trent, G. Terrones, J. D. Hudson, and E. T. Michener, 1993, Ferrocyanide Safety Program: Computational Analysis of Fluid Flow and Zonal Deposition in Ferrocyanide Single-Shell Tanks, PNL-8876, Pacific Northwest Laboratory, Richland, Washington.

McLaren, J. M., 1993, Ferrocyanide Safety Program: Updated Thermal Analysis Model for Ferrocyanide Tanks with Applications to Tank 241-BY-104, WHC-EP-0669, Westinghouse Hanford Company, Richland, Washington.

McLaren, J. M., 1994a, Ferrocyanide Safety Program: Thermal Analysis of Ferrocyanide Tanks, Group I, WHC-EP-0729, Westinghouse Hanford Company, Richland, Washington.

Meacham, J. E., R. J. Cash, and G. T. Dukelow, 1995, Quarterly Report on the Ferrocyanide Safety Program for the Period Ending June 30, 1995, WHC-EP-0474-17, Westinghouse Hanford Company, Richland, Washington.

McLaren, J. M., 1994b, Ferrocyanide Safety Program: Thermal Analysis of Ferrocyanide Watch List Tanks, Group II, WHC-EP-0794, Westinghouse Hanford Company, Richland, Washington.

Meacham, J. E., R. J. Cash, and G. T. Dukelow, 1994, Quarterly Report on the Ferrocyanide Safety Program for the Period Ending June 30, 1994, WHC-EP-0474-13, Westinghouse Hanford Company, Richland, Washington.

Mishima, J., S. L. Sutter, K. A. Hawley, C. E. Jenkins, and B. A. Napier, 1986, Potential Radiological Impacts of Upper-Bound Operational Accidents During Proposed Waste Disposal Alternatives for Hanford Defense Waste, PNL-5356, Pacific Northwest Laboratory, Richland, Washington.

Nguyen, D. M., 1989, Data Analysis of Conditions in Single-Shell Tanks Suspected of Containing Ferrocyanide, (internal memorandum 13314-89-025 to N. W. Kirch, March 2), Westinghouse Hanford Company, Richland, Washington. 
Peach, J. D., 1990, Consequences of Explosion of Hanford's Single-Shell Tanks are Understated, (letter B-241479 to C. M. Synar, Chairman of Environment, Energy and Natural Resources Subcommittee, Committee on Government Operations, House of Representatives, October 10), GAO/RCED-91-34, General Accounting Office, Washington, D.C.

Postma, A. K., R. T. Allemann, H. H. Cady, M. W. First, T. S. Kress, and J. Mishima, 1991, Meeting of Aerosol Experts Team on December 18, 1990, (memorandum to D. D. Stepnewski, Westinghouse Hanford Company, January 11), G \& P Consulting, Inc., Dallas, Oregon.

Postma, A. K., R. T. Allemann, M. D. Allen, H. H. Cady, J. R. Coleman, M. W. First, J. A. Gieseke, T. S. Kress, and J. Mishima, 1992a, Meeting of WHC Aerosol Experts Panel of March 2, 1992 (memorandum to J. M. Grigsby, Westinghouse Hanford Company, March 18), G \& P Consulting, Inc., Dallas, Oregon.

Postma, A. K., H. Babad, R. J. Cash, and J. L. Deichman, 1992b, Current Understanding of the Safety of Storing High-Level Waste Containing Ferrocyanide at the Hanford Site, WHC-EP-0531, Rev. 1, Westinghouse Hanford Company, Richland, Washington.

Postma, A. K., J. E. Meacham, G. S. Barney, G. L. Borsheim, R. J. Cash, M. D. Crippen, D. R. Dickinson, J. M. Grigsby, D. W. Jeppson, M. Kummerer, J. M. McLaren, C. S. Simmons, and B. C. Simpson, 1994, Ferrocyanide Safety Program: Safety Criteria for Ferrocyanide Watch List Tanks, WHC-EP-0691, Westinghouse Hanford Company, Richland, Washington.

Sasaki, L. M., and B. D. Valenzuela, 1994, Ferrocyanide Safety Program: Data Interpretation Report for Tank 241-T-107 Core Samples, WHC-EP-0796, Westinghouse Hanford Company, Richland, Washington.

Scheele, R. D., L. L. Burger, J. M. Tingey, S. A. Bryan, G. L. Borsheim, B. C. Simpson, R. J. Cash, and H. H. Cady, 1991, Ferrocyanide-Containing Waste Tanks:

Ferrocyanide Chemistry and Reactivity, in the Proceedings of "Environmental Restoration '91," University of Arizona, Tucson, Arizona.

Scheele, R. D., J. M. Tingey, L. L. Burger, and R. L. Fell, 1993, Effect of Potential Waste Composition on the Reactivity of Hanford Ferrocyanide Wastes-Diluent, Catalyst, Initiator Studies, PNL-8649, Pacific Northwest Laboratory, Richland, Washington.

Sheridan, T. R., 1994, Closure of the Ferrocyanide Unreviewed Safety Question, (external letter 94-SST-052 to A. L. Trego, President, Westinghouse Hanford Company, March 4), U.S. Department of Energy, Richland Operations Office, Richland, Washington. 
Simpson, B. C., G. L. Borsheim, and L. Jensen, 1993a, Tank Characterization Data Report: Tank 241-C-112, WHC-EP-0640, Rev. 1, Westinghouse Hanford Company, Richland, Washington.

Simpson, B. C., G. L. Borsheim, and L. Jensen, 1993b, Tank Characterization Report: Tank 241-C-109, WHC-EP-0668, Westinghouse Hanford Company, Richland, Washington.

Steindler, M. J., and W. B. Seefeldt, 1980, A Method for Estimating the Challenge to an Air Cleaning System Resulting from an Accidental Explosive Event. In Proceedings of the 16th DOE Nuclear Air Cleaning Conference, CONF-801038, National Technical Information Service, Springfield, Virginia. 


\section{DISTRIBUTION}

Number of copies

\section{OFFSITE}

7

U.S. Department of Energy

EM-36, Trevion II

12800 Middlebrook Road

Germantown, MD 20874

James V. Antizzo, EM-36

Charles O'Dell, EM-36 (5)

U. S. Department of Energy

Forrestal Building

1000 Independence Avenue SW

Washington, DC 20585

Shirley Campbell, EH-71

1

U.S. Department of Energy

656 Quince Diamond Road

Room 235, EM-20.1

Gaithersburg, MD 20879

Cynthia Hilland

1

U.S. Department of Energy

Savannah River Operations Office

P.O. Box A

Aiken, SC 29808

Thomas C. Temple

1

Charles S. Abrams

1987 Virginia

Idaho Falls, ID 83404

1

David O. Campbell

102 Windham Road

Oak Ridge, TN 37830 


\section{DISTRIBUTION (Continued)}

Number of copies

\section{OFFSITE}

1

Fred N. Carlson

6965 North 5th West

Idaho Falls, ID 83401

1

Billy C. Hudson

202 Northridge Court

Lindsborg, KA 67456

1

Thomas S. Kress

102-B Newridge Road

Oak Ridge, TN 37839

1

William R. Prindle

1556 Crestline Drive

Santa Barbara, CA 93105

1

Alfred Schneider

5005 Hidden Branches Drive

Dunwoody, GA 30338

1

Air Products \& Chemicals, Inc.

7201 Hamilton Blvd

Allentown, PA 18195-1501

George E. Schmauch

1

Brookhaven National Laboratory

Upton, NY 11973

Kamal K. Bandyopadhyay

1

Design Science, Inc.

163 Witherow Road

Sewickley, PA 15143

Gary Powers 


\section{DISTRIBUTION (Continued)}

Number of copies

\section{OFFSITE}

2

Fauske and Associates, Inc. 16 W070 W. 83rd St.

Burr Ridge, IL 60521

Michael Epstein

Hans K. Fauske

1

Florida State University

Department of Chemistry B-164

Tallahassee, FL 32306

Greg R. Choppin

2

G \& P Consulting, Inc. 3640 Ballard Road

Dallas, OR 97338

J. Michael Grigsby

Arlin K. Postma

1

Harvard University 295 Upland Avenue

Newton Highlands, MA 02161

Melvin W. First

1

Hazards Research Corporation

200 Valley Road, Suite 301

Mt. Arlington, NJ 07856

Chester Grelecki

Los Alamos National Laboratory

P.O. Box 1663

Los Alamos, NM 87545

Steve F. Agnew

Thomas E. Larson 


\section{DISTRIBUTION (Continued)}

Number of copies

\section{OFFSITE}

1

MIT/Department of Nuclear Engineering

77 Massachusetts Ave.

Room 24-102

Cambridge, MA 02139

Mujid S. Kazimi

$1 \quad$ Nuclear Consulting Services, Inc.

P.O. Box 29151

Columbus, OH 43229-0151

J. Louis Kovach

Oak Ridge National Laboratory

1 Emory D. Collins

P.O. Box 2008

7930, MS-6385

Oak Ridge, TN 37831-6385

1 Charles W. Forsberg

P.O. Box 2008

MS-6495

Oak Ridge, TN 37831-6495

1

Rice University

5211 Paisley

Houston, TX 77096

Andrew S. Veletsos

2

Sandia National Laboratories

P.O. Box 5800

Albuquerque, NM 87185

Dana A. Powers, MS-0744

Scott E. Slezak, MS-0741 


\section{DISTRIBUTION (Continued)}

Number of copies

\section{OFFSITE}

Science Applications International Corporation 20300 Century Blvd, Suite 200-B

Germantown, MD 20874

Ray S. Daniels (3)

State of Washington - Department of Ecology

1

Michael T. Gordon

P. O. Box 47600

Olympia, WA $98504-7600$

1

Alex Stone

1315 W. 4th Avenue

Kennewick, WA 99336

1

University of South Carolina

Department of Electrical and Computer Engineering Swearingen Engineering Center

Columbia, SC 29208

Joseph S. Byrd

1

University of Washington

Center for Process Analytical Chemistry

Chemistry Department BG-10

Seattle, WA 98195

Bruce R. Kowalski

1 Vanderbilt University

P.O. Box 1596, Station B

Nashville, TN 37235

Frank L. Parker 


\section{DISTRIBUTION (Continued)}

Number of copies

OFFSITE

1

Waste Policy Institute

555 Quince Orchard Road, Suite 600

Gaitherburg, MD 20878-1437

Donald T. Oakley

ONSITE

10

U.S. Department of Energy, Richland Operations Office

R. E. Gerton

S7-54

R. G. Harwood

S7-54

W. F. Hendrickson

S7-54

D. H. Irby (2)

S7-54

M. F. Jarvis

S7-54

A. G. Krasopoulos

A4-81

Public Reading Room

$\mathrm{H} 2-53$

RL Docket File (2)

B1-17

7

Pacific Northwest Laboratory

S. A. Bryan

P7-25

R. T. Hallen

P8-38

M. A. Lilga

P8-38

R. D. Scheele

P7-25

C. S. Simmons

K6-77

C. W. Stewart

K7-15

Hanford Technical Library

P8-55

37

Westinghouse Hanford Company

H. Babad

S7-30

J. B. Billetdeaux

S7-16

D. C. Board

T4-08

W. S. Callaway

S3-90

R. J. Cash (5)

S7-15

M. D. Crippen

L5-31 


\section{DISTRIBUTION (Continued)}

R. D. Crowe H0-38

D. R. Dickinson

L5-31

G. T. Dukelow

S7-15

M. N. Islam

R3-08

D. W. Jeppson

L5-31

N. W. Kirch

R2-11

C. A. Kuhlman

B3-30

E. J. Lipke

S7-14

L. L. Lockrem

S3-90

J. M. McLaren

H0-34

J. E. Meacham (2)

S7-15

N. J. Milliken

H4-62

S. R. Moreno

B3-06

T. V. Rebagay

T6-30

F. R. Reich

L5-63

E. F. Riedel

S3-90

B. C. Simpson

R2-12

H. Toffer

H0-38

W. T. Watson

H0-38

W. D. Winkelman

L5-55

W. D. Wittekind

H0-38

Central Files

A3-88

Correspondence Control

R1-20

EDMC

H6-08

OSTI (2)

A3-36 
This page intentionally left blank. 